\title{
Pengaruh pemberian vitamin E terhadap kadar neutrofil setelah latihan fisik
}

\author{
${ }^{1}$ Kristo Warong \\ ${ }^{2}$ Damajanty H. C. Pangemanan \\ ${ }^{2}$ Joice N. A. Engka
}

\begin{abstract}
${ }^{1}$ Kandidat Skripsi Fakultas Kedokteran Universitas Sam Ratulangi Manado
${ }^{2}$ Bagian Fisiologi Fakultas Kedokteran Universitas Sam Ratulangi Manado

Email: christoalfawarong@yahoo.co.id
\end{abstract}

\begin{abstract}
Absract: Physical exercise can improve and maintain physical fitness. However, physical exercise can lead to oxidative stress that can reduce the activity of antioxidants. Vitamin $\mathrm{E}$ is a fat-soluble antioxidant that could free radicals in the body. Neutrophils play an active role in the process of phagocytosis of bacteria and other microorganisms the damaged tissue caused by tissue injury. This study was aimed to obtain the effect of vitamin E on neutrophil count after physical exercise. This was a field experimental study with a pre post test control group design. Data were analyzed with the Mann Whitney $U(\alpha=0.05)$. The physical exercise was playing futsal for 60 minutes. Respondents were 30 male respondents divided into 2 groups: treatment and control groups. The levels of neutrophils were examined after physical exercise and after the administration of vitamin E 400 IU for seven days. Data analysis of the effect of vitamin $E$ on neutrophil level after physical exercise showed a $p$ value of 0.031 . Conclusion: Vitamin E influenced the levels of neutrophils after physical exercise.
\end{abstract}

Keywords: physical exercise, oxidative stress, vitamin E, neutrophil

\begin{abstract}
Abstrak: Latihan fisik merupakan aktivitas yang dilakukan seseorang untuk meningkatkan atau memelihara kebugaran tubuh. Latihan fisik dapat menimbulkan stres oksidatif sehingga dapat menurunkan aktivitas antioksidan. Vitamin E merupakan antioksidan yang larut dalam lemak dan berfungsi untuk mengurangi radikal bebas yang terdapat dalam tubuh. Neutrofil berperan aktif dalam proses fagositosis bakteri, mikroorganisme, dan membersihkan sisa jaringan rusak yang disebabkan oleh cedera jaringan. Penelitian ini bertujuan untuk mengetahui pengaruh vitamin E terhadap kadar neutrofil setelah latihan fisik. Jenis penelitian ialah eksperimental lapangan dengan pre post test control group design. Untuk menguji signifikansi penelitian digunakan uji Mann Whitney $U(\alpha=0,05)$. Latihan fisik berupa olahraga futsal selama 60 menit dilakukan oleh 30 responden laki-laki yang dibagi dalam 2 kelompok yaitu perlakuan dan kontrol. Kadar neutrofil diukur setelah latihan fisik dan setelah pemberian vitamin E 400 IU selama 7 hari. Hasil statistik menunjukkan terdapat pengaruh bermakna dari vitamin E pada kelompok perlakuan $(p=0,031)$. Simpulan: Terdapat pengaruh vitamin $\mathrm{E}$ terhadap kadar neutrofil setelah latihan fisik.
\end{abstract}

Kata kunci: latihan fisik, stres oksidatif, vitamin E, neutrofil

Latihan fisik merupakan aktivitas yang dilakukan seseorang untuk meningkatkan atau memelihara kebugaran tubuh. Latihan fisik meningkatkan pelepasan neutrofil ke sirkulasi dan memiliki kapasitas untuk menghasilkan beberapa bentuk dari
Reactive Oxygen Species (ROS)., ${ }^{1,2}$ Radikal bebas adalah senyawa yang kehilangan elektron, molekul tersebut menjadi tidak stabil dan selalu berusaha mengambil elektron dari molekul atau sel lain. Radikal bebas diproduksi secara 
normal pada fungsi imunitas yang diperlukan oleh sel imun untuk membunuh patogen dan mengeluarkannya. Produksi berlebihan pada kondisi patogenik menyebabkan kerusakan sel imun dan menimbulkan imunosupresi. 3,4

Neutrofil merupakan salah satu komponen sel darah putih yang berfungsi sebagai fagosit. Sel-sel ini merupakan pertahanan pertama pada invasi bakteri sehingga sangat penting dalam respon peradangan. 5

Vitamin E merupakan antioksidan yang larut dalam lemak yang dapat membantu mencegah kerusakan sel-sel tubuh. ${ }^{2,6}$ Belum dapat dijelaskan bahwa vitamin $E$ berperan langsung dalam proses pemulihan jaringan atau berperan secara tidak langsung dalam proses tersebut. Penelitian ini bertujuan untuk mengetahui pengaruh vitamin $\mathrm{E}$ terhadap kadar neutrofil setelah latihan fisik.

\section{METODE PENELITIAN}

Jenis penelitian ini ialah eksperimental dengan prepost test control group design. Penelitian ini dilaksanakan pada tanggal 1523 Januari 2016. Populasi penelitian ini ialah mahasiswa Fakultas Kedokteran Unsrat angkatan 2012. Responden sebanyak 30 orang laki-laki berusia 19-21 tahun yang dibagi menjadi dua kelompok yaitu kelompok perlakuan dan kontrol. Latihan fisik pada penelitian ini yaitu olahraga futsal yang dilakukan selama 60 menit.

Kelompok perlakuan diambil sampel darah untuk pemeriksaan kadar neutrofil setelah latihan fisik dan setelah diberikan vitamin E 400 IU selama 7 hari. Kelompok kontrol diambil sampel darah untuk diperiksa kadar neutrofil setelah latihan fisik dan setelah 7 hari tanpa pemberian vitamin E 400 IU.

\section{HASIL PENELITIAN}

Tabel 1 memperlihatkan rerata denyut nadi sesudah latihan fisik pada kelompok kontrol lebih tinggi yaitu 171,2 kali per menit dibandingkan kelompok perlakuan yaitu 162,2 kali per menit.
Tabel 1. Rerata denyut nadi setelah latihan fisik

\begin{tabular}{ccc}
\hline Kelompok & $\mathbf{N}$ & Rerata $(\mathbf{x} /$ menit $)$ \\
\hline Perlakuan & 15 & 162,2 \\
\hline Kontrol & 15 & 171,2 \\
\hline
\end{tabular}

Tabel 2 memperlihatkan rerata kadar neutrofil pada kelompok perlakuan dan kelompok kontrol mengalami penurunan sesudah pemberian vitamin $E$ pada kelompok perlakuan dan tanpa pemberian vitamin E pada kelompok kontrol.

Tabel 2. Rerata kadar neutrofil sebelum dan sesudah pada kelompok perlakuan dan kontrol

\begin{tabular}{lcc}
\hline Kelompok & \multicolumn{2}{c}{ Rerata kadar neutrofil } \\
& Sebelum (\%) & Sesudah $(\%)$ \\
\hline Perlakuan & 63,2 & 54 \\
\hline Kontrol & 64,7 & 60,8 \\
\hline
\end{tabular}

Tabel 3 memperlihatkan rerata penurunan kadar neutrofil pada kelompok perlakuan lebih besar daripada kelompok kontrol

Tabel 3. Rata-rata penurunan kadar neutrofil pada kelompok perlakuan dan kontrol

\begin{tabular}{lcc}
\hline Kelompok & n & Rerata (\%) \\
\hline Perlakuan & 15 & 9,15 \\
Kontrol & 15 & 3,91 \\
\hline
\end{tabular}

Tabel 4 memperlihatkan hasil uji statistik dengan nilai $\mathrm{p}=0,031 \quad(<0,05)$. Berdasarkan uji statistik Mann Whitney U, terdapat perbedaan bermakna penurunan kadar neutrofil antara kedua kelompok.

\section{BAHASAN}

Pada penelitian ini didaptkan rerata denyut nadi setelah latihan fisik pada kelompok perlakuan ialah 162,2 kali per menit dan pada kelompok kontrol ialah 171,2. Menurut American Heart Association Subcommittee, intensitas latihan yang dicapai oleh kelompok perlakuan dan kelompok kontrol termasuk dalam intensitas tinggi 77-94\% dari denyut jantung maksimal. Untuk usia 20-21 tahun, denyut nadi pada intensitas tinggi ialah 160-197 kali per menit. ${ }^{7}$ 
Tabel 4. Hasil analisis statistik

\begin{tabular}{llccc}
\hline & Mann-Whitney U & Wilcoxon W & Z & $\begin{array}{c}\text { Asymp.p. sig. (1- } \\
\text { tailed) }\end{array}$ \\
\hline Neutrofil & 60,500 & 180,500 & $-2,158$ & 0,031 \\
\hline
\end{tabular}

Pada kelompok perlakuan dan kontrol terdapat penurunan kadar neutrofil setelah latihan fisik dan 7 hari setelah pemberian vitamin $\mathrm{E}$, tetapi masih lebih rendah pada kelompok perlakuan dibandingkan dengan kelompok kontrol dengan rerata neutrofil pada kelompok perlakuan ialah $54.073 \%$ dan kelompok kontrol $60.800 \%$.

Hal ini terjadi karena setelah latihan fisik intensitas tinggi terdapat cedera jaringan yang menyebabkan peningkatan produksi radikal bebas yang memicu terjadinya ketidakseimbangan antara sistem pertahanan antioksidan dengan produksi radikal bebas sehingga memicu neutrofil masuk ke dalam sirkulasi. Pada saat 7 hari setelah latihan fisik, keseimbangan sistem pertahanan antioksidan kembali ke kondisi yang normal sehingga kadar neutrofil mengalami penurunan. ${ }^{8}$

Latihan fisik dapat memicu stress oksidatif sehingga dapat menurunkan aktivitas antioksidan di dalam tubuh. Ketika aktivitas antioksidan terganggu, maka terjadi penimbunan superoksida dan hidrogen peroksida sehingga terbentuk reaksi berantai yang dapat menyebabkan cedera dan peradangan jaringan. Pada saat terjadi kerusakan jaringan, leukosit khususnya neutrofil yang pertama kali datang di tempat cedera atau peradangan. Senyawa kimia yang dilepaskan oleh jaringan yang cedera merupakan faktor yang memicu neutrofil teraktivasi. Hal ini merupakan salah satu respon fisiologis untuk pertahanan tubuh. 1,2

Hasil statistik menunjukkan terdapat perbedaan bermakna penurunan kadar neutrofil pada kelompok perlakuan dan kelompok kontrol. Hal ini sejalan dengan penelitian yang dilakukan oleh Davison dan Gleeson terhadap 6 orang laki-laki yang diberi latihan bersepeda selama 2,5 jam pada $60 \%$ VO2maks dengan pemberian suplementasi vitamin $\mathrm{C}$ dengan atau tanpa karbohidrat yang dikonsumsi dalam bentuk minuman. Total leukosit kelompok kontrol yang mendapatkan karbohidrat saja dan kelompok yang mendapat karbohidra sertat vitamin $\mathrm{C}$ meningkat secara bermakna segera setelah latihan. Secara statistik terdapat perbedaan bermakna antara kelompok perlakuan yang diberikan karbohidrat kombinasi vitamin $\mathrm{C}$ dengan kelompok kontrol yang hanya diberikan karbohidrat. ${ }^{9}$

Penelitian lain yang dilakukan oleh Ozaslan et al. dengan menggunakan suplemen vitamin $\mathrm{C}$ pada tikus yang dibagi dalam 4 kelompok, yaitu 1 kelompok kontrol dan 3 kelompok intervensi dengan dosis yang berbeda, Pada 3 kelompok perlakuan ini terdapat peningkatan jumlah leukosit. Secara statistik terdapat perbedaan bermakna antara kelompok perlakuan dengan kelompok kontrol. ${ }^{9}$

Kadar neutrofil meningkat setelah latihan dibandingkan dengan sebelum latihan, meskipun masih dalam batas normal. Latihan aerobik yang dilakukan bagi pemula dapat menyebabkan cedera atau kerusakan jaringan. Kerusakan dan peradangan jaringan ini disebabkan oleh lepasnya elektron sewaktu melakukan latihan aerobik. ${ }^{10}$

Pada penelitian ini, diberikan suplemen vitamin E yang sudah dikenal sebagai salah satu antioksidan. Hasil penelitian tentang efek vitamin $E$ terhadap stres oksidatif karena latihan fisik masih bervariasi. Pemberian antioksidan dalam hal ini Vitamin E dapat menurunkan stres oksidatif karena latihan. ${ }^{10}$

Penurunan kadar neutrofil menunjukkan bahwa pemberian suplemen Vitamin E dapat meningkatkan kadar vitamin E dalam darah dan terjadinya cedera atau peradangan dapat dihambat sehingga kadar 
neutrofil tidak mengalami peningkatan yang tinggi.

\section{SIMPULAN}

Dari hasil penelitian dapat disimpulkan bawha terdapat pengaruh vitamin $\mathrm{E}$ terhadap kadar neutrofil setelah latihan fisik.

\section{SARAN}

Bagi yang akan melakukan penelitian selanjutnya diharapkan menambah jumlah sampel, menambah durasi latihan fisik, dan meningkatkan waktu pemberian vitamin $\mathrm{E}$.

\section{DAFTAR PUSTAKA}

1. Irawan MA. Olahraga dan peningkatan radikal bebas. 2009. [cited 21 Okt 2015]. Available from: URL: http://pssplab.com/book/?p=2 90

2. Youngsen R. Antioksidan, manfaat vitamin $\mathrm{C}$ dan $\mathrm{E}$ bagi kesehatan. 2003. $15-46$.

3. Febriandi A. Apa itu radikal bebas dan antioksidan? 2010. [cited 25 Okt 2015]. Available from: URL: http://akhiajun.wordpress.com/2010/04/ 01/apa-itu-radikal-bebas-apa-itu-antioksidan/

4. Mustafid Z. Imunitas tubuh. 2009 [cited 25 Okt 2015]. Available from: URL:http://www.scribd.com/doc/1200 8763/Imunitas.
5. Guyton, Hall. Fisiologi Kedokteran (9th ed). Jakarta: EGC, 1997.

6. Vitamin E (tocopherol). [cited 25 Okt 2015]. Available from: URL: http://www. ghehealth.com/vitamin-etocopherol.html.

7. American Heart Association Subcommittee on rehabilitation target group. Standards for cardiovascular exercise treatment programs. Circulation. 1979;59:1084-9

8. Cooper CE, Vollaard BJ, Choueiri T, Wilson MT. Exercise, free radicals and oxidative stress. Biochemical society. 2002;30(2):280-5.

9. Mahfida Silvi, Kandarina B.J, Farmawati Arta. Efektifitas minuman kombinasi maltodekstrin dan vitamin $\mathrm{C}$ terhadap hitung jenis leukosit pada atlet sepak bola. Universitas Gadjah Mada. [cited 9 Nov 2015]. Available from: http://etd.repository.ugm.ac.id/downloa dfile/84043/potong an/S2-2015339869-introduction.pdf

10. Ulvie NY, Lestariana $W$, Muttaqien $Z$. Perbedaan jumlah leukosit setelah konsumsi jus jambu biji merah selama latihan aerobik bagi pemula. 2013. [cited 9 Nov 2015]. Available from: https://publikasiilmiah.ums.ac.id/bitstre am/handle/11617/2997/1_PERBEDAA N\%20JUMLAH\%20LEUKOSIT\%20S ETELAH\%20KONSUMSI\%20JUS.pd f?sequence $=1$ 